\title{
Ion channels expression and function are strongly modified in solid tumors and vascular malformations
}

\author{
Antonella Biasiotta ${ }^{1 \dagger}$, Daniela D’Arcangelo ${ }^{2 \dagger}$, Francesca Passarelli ${ }^{2}$, Ezio Maria Nicodemi ${ }^{2 *}$ \\ and Antonio Facchiano ${ }^{2^{*}}$
}

\begin{abstract}
Background: Several cellular functions relate to ion-channels activity. Physiologically relevant chains of events leading to angiogenesis, cell cycle and different forms of cell death, require transmembrane voltage control. We hypothesized that the unordered angiogenesis occurring in solid cancers and vascular malformations might associate, at least in part, to ion-transport alteration.

Methods: The expression level of several ion-channels was analyzed in human solid tumor biopsies. Expression of 90 genes coding for ion-channels related proteins was investigated within the Oncomine database, in 25 independent patients-datasets referring to five histologically-different solid tumors (namely, bladder cancer, glioblastoma, melanoma, breast invasive-ductal cancer, lung carcinoma), in a total of 3673 patients (674 control-samples and 2999 cancer-samples). Furthermore, the ion-channel activity was directly assessed by measuring in vivo the electrical sympathetic skin responses (SSR) on the skin of 14 patients affected by the flat port-wine stains vascular malformation, i.e., a non-tumor vascular malformation clinical model.

Results: Several ion-channels showed significantly increased expression in tumors ( $p<0.0005$ ); nine genes (namely, CACNA1D, FXYD3, FXYD5, HTR3A, KCNE3, KCNE4, KCNN4, CLIC1, TRPM3) showed such significant modification in at least half of datasets investigated for each cancer type. Moreover, in vivo analyses in flat port-wine stains patients showed a significantly reduced SSR in the affected skin as compared to the contralateral healthy skin $(p<0.05)$, in both latency and amplitude measurements.

Conclusions: All together these data identify ion-channel genes showing significantly modified expression in different tumors and cancer-vessels, and indicate a relevant electrophysiological alteration in human vascular malformations. Such data suggest a possible role and a potential diagnostic application of the ion-electron transport in vascular disorders underlying tumor neo-angiogenesis and vascular malformations.
\end{abstract}

Keywords: Cancer, lon-channels, Autonomic nervous system, Sympathetic skin response, SSR, Flat port-wine stains

\section{Background}

Several key cellular functions are related to transmembrane potentials and lie under the control of ion channels, pumps and gap junction complexes. Controlling

\footnotetext{
*Correspondence: em.nicodemi@idi.it; a.facchiano@idi.it

${ }^{\dagger}$ Antonella Biasiotta and Daniela D’Arcangelo contributed equally to this work

${ }^{2}$ Istituto Dermopatico dell'Immacolata, IDI-IRCCS, Fondazione Luigi Maria Monti, via Monti di Creta 104, 00167 Rome, Italy

Full list of author information is available at the end of the article
}

transmembrane voltage represents a fundamental process in many physiologically relevant steps, including cell cycle progression [1] and different forms of cell death $[2,3]$. Over expression or increased activity of ion channels has been demonstrated as a response to mitogens exposure [4-6]. Several studies show a direct link between the transmembrane ion flow and carcinogenesis $[7,8]$. However, as pointed out [9], the role membrane potential plays in the pathogenesis of several disorders, including cancer, is still not well understood. Plasma 
membrane de-polarization has a pivotal role at different stages of cell cycle progression and in various cell types [9]. Namely, endothelial cells hyper-polarization has been shown to contribute to cell division arrest [10], and channels are known to control migratory cellular properties in wound healing [11]. Further, $\mathrm{Ca}^{2+}, \mathrm{K}^{+}$and $\mathrm{Cl}^{-}$ channels are essential regulators of cell proliferation and cancer development [12-16]. As recently further demonstrated, several ion-channels are directly involved in controlling tumor-[17] as well as non-tumor angiogenesis [18]. Expression and activity of TRPV4 channel have been found suppressed in tumor endothelium [19], and its activation has been found to normalize tumor vessels [20]; inhibiting $\mathrm{Cl}^{-}$channel activity has anti-angiogenesis and anti-glioma properties [21]; finally, human voltagedependent $\mathrm{K}^{+}$channel has been found associated with cancer aggressiveness and angiogenesis [22]. Therefore, ion-channels play a fundamental role in cancer progression as well as in angiogenesis.

Flat port-wine stains are non-tumor malformations of the skin capillaries [23]. Cutaneous capillary malformations are usually isolated finding. However, they may occasionally coexist with cerebral or ocular vascular malformations, constituting the rare sporadic neurocutaneous Sturge-Weber syndrome (SWS) affecting the cephalic microvasculature, or may represent signs of more aggressive vascular malformations or even vascular tumors.

The sympathetic skin response (SSR) is an alteration in skin electrical potential evoked by strong stimuli; it consists of a multineuronal reflex activated by a variety of afferent inputs where the efferent branches involve sympathetic sudomotor fibers. The electrodermal activity reflects sympathetic cholinergic sudomotor function which induces changes in skin resistance to electrical conduction. The response is mediated by ions flux via activation of receptor-coupled $\mathrm{Ca}^{2+}, \mathrm{Cl}^{-}$and $\mathrm{K}^{+}$channels [24]. Since SSR reflects peripheral C fibers activity, it is considered a reliable quantitative measure of sympathetic function and dysfunction as well as in polyneuropathies and dysautonomic disorders [25-27].

We have previously shown novel serum markers able to indicate cardiovascular diseases, $[28,29]$ as well as soluble factors able to affect angiogenesis [30] and to discriminate infantile hemangioma from more aggressive vascular malformations or tumors [31]. We also investigated novel molecular markers of melanoma set-up and progression [32].

In the present study, we further addressed the issue of altered angiogenesis in tumor and non-tumor conditions. The expression level of 90 ion-channel genes was investigated in five different solid tumors, having a different histological origin. The expression level of several ion-channels genes was found to be strongly modified; we thus hypothesized that ion-transport may represent a measurable sign of the altered underlying angiogenesis. We, therefore, measured in vivo the ion-channel function in a human vascular malformation model, namely flat port-wine stains, as a model to test electrical-stimuli transport in a human vascular disorder accepted by the Ethic Committee.

\section{Methods}

\section{lon-channel gene expression investigation}

Gene expression levels were investigated by accessing human cancer datasets available at Oncomine (http:// www.oncomine.org). The current Oncomine version contains several hundred different patients-datasets, referring to tumors biopsies obtained from almost any histological source; unfortunately vascular tumors (such as hemangioma, angiomas, hemangioendothelioma, angiosarcoma) are lacking from such database. In the current study 25, independent datasets from histologically different solid tumors were investigated, namely, bladder cancer, glioblastoma, melanoma, breast cancer, lung adenocarcinoma, as indicated in details in Table 1.

Table 2 reports the detailed list of the 90 ion-channels and ion-channel related genes investigated in the present study. Briefly, different members were selected from 21 channel families, namely: amiloride-sensitive cation channels, calcium Channels voltage-dependent, cation channels sperm associated, FXYD domain containing ion transport regulators, gamma-aminobutyric acid (GABA) receptors, glutamate receptors ionotropic, potassium channels voltage gated subfamily, cholinergic receptors (Nicotinic), chloride channels, cyclic nucleotide gated channels, glutamate Receptors, sodium leak channels, purinergic receptors P2X, sodium-hydrogen exchanger regulatory factor 4, regulatory solute carrier proteins, sodium channels, glucose activated Ion channels, two pore segment channels, transient receptor potential cation channels, zinc activated ion channels, aquaporins.

Expression of such 90 genes was evaluated in oncomine database by setting "cancer vs. normal analysis" and choosing as cancer type: "superficial bladder cancer" within the bladder cancer group, "glioblastoma" within the brain and CNS cancer group, "breast invasive ductal carcinoma" within the breast cancer group, "lung adenocarcinoma" within the lung cancer group, and "melanoma".

Expression fold change (cancer vs. normal samples) and $p$ values were reported for each analysis. Gene expression in tissue biopsies from 3673 patients was analyzed. Namely, 674 control-samples and 2999 cancer-samples were investigated.

Two additional datasets were identified and investigated within GEO database from NCBI (http://www. 
Table 1 Tumors types, datasets names, patients numerosity and reference of each dataset investigated in the present study, from oncomine database (http://www.oncomine.org)

\begin{tabular}{|c|c|c|c|c|}
\hline & Tumor type and dataset name & No of control samples & No of cancer samples & References $\mathrm{n}$. \\
\hline \multicolumn{5}{|c|}{ Superficial bladder cancer } \\
\hline 1 & Dyrskjot dataset & 14 & 28 & [86] \\
\hline 2 & Lee dataset & 68 & 126 & [87] \\
\hline 3 & Sanchez dataset & 48 & 28 & [88] \\
\hline 4 & Blaveri dataset & 2 & 25 & [89] \\
\hline \multicolumn{5}{|c|}{ Glioblastoma } \\
\hline 5 & Lee dataset & 3 & 78 & {$[90]$} \\
\hline 6 & Bredel dataset & 4 & 26 & [91] \\
\hline 7 & Sun dataset & 23 & 81 & [92] \\
\hline 8 & Murat dataset & 4 & 80 & [93] \\
\hline \multicolumn{5}{|c|}{ Melanoma } \\
\hline 9 & Talantov dataset & 7 & 45 & [94] \\
\hline 10 & Riker dataset & 5 & 14 & [95] \\
\hline 11 & Critchley dataset & 23 & 23 & [96] \\
\hline 12 & Haqq dataset & 3 & 23 & [97] \\
\hline \multicolumn{5}{|c|}{ Breast invasive ductal cancer } \\
\hline 13 & Ma dataset & 28 & 18 & [98] \\
\hline 14 & Curtis dataset & 144 & 1556 & [99] \\
\hline 15 & Radvanji dataset & 5 & 26 & {$[100]$} \\
\hline 16 & Turashvi dataset & 20 & 5 & {$[101]$} \\
\hline 17 & Zhao dataset & 4 & 154 & [102] \\
\hline \multicolumn{5}{|c|}{ Lung adenocarcinoma } \\
\hline 18 & Bhattacharjee dataset & 17 & 139 & [103] \\
\hline 19 & Beer dataset & 10 & 86 & [104] \\
\hline 20 & Stearman dataset & 19 & 20 & {$[105]$} \\
\hline 21 & Hou dataset & 65 & 45 & {$[106]$} \\
\hline 22 & Okayama dataset & 20 & 226 & [107] \\
\hline 23 & Selamat dataset & 58 & 58 & {$[108]$} \\
\hline 24 & Landi dataset & 49 & 58 & [109] \\
\hline 25 & Su dataset & 31 & 31 & [110] \\
\hline Totals & & 674 & 2999 & \\
\hline
\end{tabular}

ncbi.nlm.nih.gov/gds), namely GSE41614 and GSE44115. Such datasets specifically refer to the vessels component within cancer samples; they were analyzed by means of the GEO2R interface available at the http://www.ncbi. nlm.nih.gov/gds site.

\section{Patients recruitment}

Several reports indicate that direct electrical stimulation may affect cell proliferation and dissemination in oncological setups and may induce other physiological effects [33-39]. Thus a clinical-study involving any electrical stimulation in cancer patients would be not acceptable by the Ethic Committee, according to the articles n. 14 and n. 16 of the Helsinki declaration on biomedical studies involving human patients, and to the article n. 16 of the Oviedo Convention.

For such reasons we submitted to the Ethic Committee the request to authorize the in vivo investigation in nontumor patients showing a pathological condition resembling, at least in part, the tumor neo-angiogenesis. Such request was authorized by the Ethic Committee and this explains way we investigated the SSR in angioma patients.

Fourteen patients (six males and eight females) affected by cutaneous flat port-wine stains were recruited at IDIIRCCS, Rome. The study was approved by the institutional review board of IDI-IRCCS Hospital, Rome (IDI Ethic Committee 2011, n. 363). Patients with flat portwine stains diagnosis (age 18-70 years) undergoing no 


\section{Table 2 Complete list of ion-channel genes and ion-channel related genes investigated}

\begin{tabular}{|c|c|c|}
\hline Gene family & Gene name & Whole gene name \\
\hline \multicolumn{3}{|c|}{ (A) Amiloride-sensitive cation channel } \\
\hline 1 & ACCN1 & Amiloride-sensitive cation channel 1 \\
\hline 2 & ACCN2 & Amiloride-sensitive cation channel 2 \\
\hline 3 & ACCN3 & Amiloride-sensitive cation channel 3 \\
\hline 4 & ACCN4 & Amiloride-sensitive cation channel 4 \\
\hline \multicolumn{3}{|c|}{ (B) Calcium channel, voltage-dependent } \\
\hline 5 & CACNA1A & Calcium channel, voltage-dependent, P/Q type, alpha 1A Subunit \\
\hline 6 & CACNA1B & Calcium channel, voltage-dependent, N type, alpha 1B Subunit \\
\hline 7 & CACNA1C & Calcium channel, voltage-dependent, L type, alpha 1C Subunit \\
\hline 8 & CACNA1D & Calcium channel, voltage-dependent, L type, alpha 1D Subunit \\
\hline \multicolumn{3}{|c|}{ (C) Cation channel, sperm associated } \\
\hline 9 & CATSPER1 & Cation channel, sperm associated 1 \\
\hline 10 & CATSPER2 & Cation channel, sperm associated 2 \\
\hline 11 & CATSPER3 & Cation channel, sperm associated 3 \\
\hline 12 & CATSPER4 & Cation channel, sperm associated 4 \\
\hline \multicolumn{3}{|c|}{ (D) FXYD domain containing ion transport regulator } \\
\hline 13 & FXYD1 & FXYD domain containing ion transport regulator 1 \\
\hline 14 & FXYD2 & FXYD domain containing ion transport regulator 2 \\
\hline 15 & FXYD3 & FXYD domain containing ion transport regulator 3 \\
\hline 16 & FXYD4 & FXYD domain containing ion transport regulator 4 \\
\hline 17 & FXYD5 & FXYD domain containing ion transport regulator 5 \\
\hline \multicolumn{3}{|c|}{ (E) Gamma-aminobutyric acid (GABA) A receptor } \\
\hline 18 & GABRA1 & Gamma-aminobutyric acid (GABA) A receptor, alpha 1 \\
\hline 19 & GABRB3 & Gamma-aminobutyric acid (GABA) A receptor, beta 3 \\
\hline 20 & GABRP & Gamma-aminobutyric acid (GABA) A receptor, Pi \\
\hline \multicolumn{3}{|c|}{ (F) Glutamate receptor, ionotropic } \\
\hline 21 & GRIA1 & Glutamate receptor, ionotropic, AMPA 1 \\
\hline 22 & GRIN2A & Glutamate receptor, ionotropic, N-methyl D-aspartate 2A \\
\hline 23 & HTR3A & 5-Hydroxytryptamine (serotonin) receptor 3A, ionotropic \\
\hline 24 & HTR3B & 5-Hydroxytryptamine (serotonin) receptor 3B, ionotropic \\
\hline \multicolumn{3}{|c|}{ (G) Potassium channel, voltage gated subfamily } \\
\hline 25 & KCNE3 & Potassium channel, voltage gated subfam.E regulatory beta Sub. 3 \\
\hline 26 & KCNE4 & Potassium channel, voltage gated subfam.E regulatory beta Sub. 4 \\
\hline 27 & $\mathrm{KCNH} 2$ & $\begin{array}{l}\text { Potassium channel, voltage gated Eag related subfamily H, } \\
\text { member } 2\end{array}$ \\
\hline 28 & $\mathrm{KCNH} 1$ & Potassium channel, voltage gated Eag relat.subfam.H, Member 1 \\
\hline 29 & KCNJ11 & Potassium channel, inwardly rectifying subfamily J, member 11 \\
\hline 30 & KCNJ12 & Potassium channel, inwardly rectifying subfamily J, member 12 \\
\hline 31 & KCNMA1 & $\begin{array}{l}\text { Potassium channel, calcium activated large conductance } \\
\text { subfam.M alpha, member } 1\end{array}$ \\
\hline 32 & KCNMB2 & Potassium channel subfamily M regulatory beta subunit 2 \\
\hline 33 & KCNMB4 & Potassium channel subfamily M regulatory beta subunit 4 \\
\hline 34 & KCNQ1 & Potassium channel, voltage gated KQT-Like Subfam. Q, Member 1 \\
\hline 35 & KCNRG & Potassium channel regulator, protein CLLD4 \\
\hline 36 & KCNV1 & Potassium channel, voltage gated modifier subfamily $\vee$, Member 1 \\
\hline 37 & KCNN1 & $\begin{array}{l}\text { Potassium channel, calcium activated intermediate/small con- } \\
\text { ductance subfamily } \mathrm{N} \text { alpha, member } 1\end{array}$ \\
\hline 38 & KCNN2 & $\begin{array}{l}\text { Potassium channel, calcium activated intermediate/small con- } \\
\text { ductance subfamily N alpha, member } 2\end{array}$ \\
\hline 39 & KCNN3 & $\begin{array}{l}\text { Potassium channel, calcium activated intermediate/small con- } \\
\text { ductance subfamily } \mathrm{N} \text { alpha, member } 3\end{array}$ \\
\hline
\end{tabular}


Table 2 continued

\begin{tabular}{|c|c|c|}
\hline Gene family & Gene name & Whole gene name \\
\hline 40 & KCNN4 & $\begin{array}{l}\text { Potassium channel, calcium activated intermediate/small con- } \\
\text { ductance subfamily } \mathrm{N} \text { alpha, member } 4\end{array}$ \\
\hline \multicolumn{3}{|c|}{$(H)$ Cholinergic receptor, nicotinic } \\
\hline 41 & CHRNA1 & Cholinergic receptor, nicotinic, alpha 1 (muscle) \\
\hline 42 & CHRNA2 & Cholinergic receptor, nicotinic, alpha 2 (neuronal) \\
\hline 43 & CHRNA3 & Cholinergic receptor, nicotinic, alpha 3 (neuronal) \\
\hline 44 & CHRNA5 & Cholinergic receptor, nicotinic, alpha 5 (neuronal) \\
\hline \multicolumn{3}{|c|}{ (I) Chloride channel } \\
\hline 45 & CFTR & Cystic fibrosis transmembrane conductance regulator \\
\hline 46 & BEST1 & Bestrophin 1 \\
\hline 47 & CLCN1 & Chloride channel 1, skeletal muscle (CIC-1) \\
\hline 48 & CLCN5 & Chloride channel, voltage-sensitive 5 (CIC-5) \\
\hline 49 & CLIC1 & Chloride intracellular channel 1 \\
\hline 50 & CLIC4 & Chloride intracellular channel 4 \\
\hline \multicolumn{3}{|c|}{ (L) Cyclic nucleotide gated channel } \\
\hline 51 & CNGB3 & Cyclic nucleotide gated channel beta 3 \\
\hline \multicolumn{3}{|c|}{ (M) Glutamate receptor } \\
\hline 52 & GRID1 & Glutamate receptor, ionotropic, delta 1 \\
\hline 53 & GRID2 & Glutamate receptor, ionotropic, delta 2 \\
\hline \multicolumn{3}{|c|}{ (N) Sodium leak channel } \\
\hline 54 & NALCN & Sodium leak channel, non selective \\
\hline \multicolumn{3}{|c|}{ (O) Purinergic receptor $P 2 X$} \\
\hline 55 & $\mathrm{P} 2 \mathrm{RX} 1$ & Purinergic receptor $\mathrm{P} 2 \mathrm{X}$, ligand gated ion channel, 1 \\
\hline 56 & $\mathrm{P} 2 \mathrm{R} \times 2$ & Purinergic receptor P2X, ligand gated ion channel, 2 \\
\hline 57 & $P 2 R \times 3$ & Purinergic receptor $\mathrm{P} 2 \mathrm{X}$, ligand gated ion channel, 3 \\
\hline 58 & $\mathrm{P} 2 \mathrm{RX} 4$ & Purinergic receptor P2X, ligand gated ion channel, 4 \\
\hline 59 & P2RX6 & Purinergic receptor P2X, ligand gated ion channel, 6 \\
\hline 60 & $\mathrm{P} 2 \mathrm{R} X 7$ & Purinergic receptor P2X, ligand gated ion channel, 7 \\
\hline \multicolumn{3}{|c|}{$(P)$ Sodium-hydrogen exchanger regulatory factor 4} \\
\hline 61 & PDZD3 & PDZ domain containing 3 \\
\hline \multicolumn{3}{|c|}{ (Q) Regulatory solute carrier protein } \\
\hline 62 & $\mathrm{RSC} 1 \mathrm{~A} 1$ & Regulatory solute carrier protein, family 1, member 1 \\
\hline \multicolumn{3}{|c|}{ (R) Sodium channel } \\
\hline 63 & SCN1A & Sodium channel, voltage gated, type I alpha subunit \\
\hline 64 & SCN2A & Sodium channel, voltage gated, type II alpha subunit \\
\hline 65 & SCN3A & Sodium channel, voltage gated, type III alpha subunit \\
\hline 66 & SCN4A & Sodium channel, voltage gated, type IV alpha subunit \\
\hline 67 & SCN5A & Sodium channel, voltage gated, type $V$ alpha subunit \\
\hline 68 & SCN8A & Sodium channel, voltage gated, type VIII alpha subunit \\
\hline \multicolumn{3}{|c|}{ (S) Glucose activated ion channel } \\
\hline 69 & SLC5A4 & Solute carrier family 5 (glucose activated ion channel) \\
\hline \multicolumn{3}{|c|}{ (T) Two pore segment channel } \\
\hline 70 & TPCN1 & Two pore segment channel 1 \\
\hline 71 & TPCN2 & Two pore segment channel 2 \\
\hline \multicolumn{3}{|c|}{ (W) Transient receptor potential cation channel } \\
\hline 72 & TRPC 1 & Transient recep. potential cation channel, subfamily C, member 1 \\
\hline 73 & TRPC2 & Transient recep. potential cation channel, subfamily C, member 2 \\
\hline 74 & TRPC3 & Transient recep. potential cation channel, subfamily C, member 3 \\
\hline 75 & TRPC4 & Transient recep. potential cation channel, subfamily C, member 4 \\
\hline 76 & TRPM1 & Transient recep. potential cation channel, subfamily M, member 1 \\
\hline
\end{tabular}


Table 2 continued

\begin{tabular}{lll}
\hline Gene family & Gene name & Whole gene name \\
\hline 77 & TRPM2 & Transient recep. potential cation channel, subfamily M, member 2 \\
78 & TRPM3 & Transient recep. potential cation channel, subfamily M, member 3 \\
79 & TRPM4 & Transient recep. potential cation channel, subfamily M, member 4 \\
80 & TRPM7 & Transient recep. potential cation channel, subfamily M, member 7 \\
81 & TRPV1 & Transient recep. potential cation channel, subfamily V, Member 1 \\
82 & TRPV2 & Transient recep. potential cation channel, subfamily V, member 2 \\
83 & TRPV3 & Transient recep. potential cation channel, subfamily V, member 3 \\
84 & TRPV4 & Transient recep. potential cation channel, subfamily V, member 4 \\
(Y) Zinc activated ion channel & & \\
85 & ZACN & Zinc activated ligand-gated ion channel \\
(Z) Acquaporins & & \\
86 & AQP1 & Aquaporin 1 \\
87 & AQP2 & Aquaporin 2 \\
88 & AQP3 & Aquaporin 3 \\
89 & AQP4 & Aquaporin 4 \\
90 & AQP5 & Aquaporin 5 \\
\hline
\end{tabular}

treatment of any type were consecutively recruited. Patients did not show systemic or neurological disorders nor obvious psychological problems. Physical general and neurological examination were normal in all cases. The average lesion was about $25 \mathrm{~cm} \times 10 \mathrm{~cm}$, typically a portion of the limb. All patients signed an informed consent to participate in the study.

\section{Sympathetic skin responses SSR recording}

SSR study was carried out according to the technical standards of the International Federation of Clinical Neurophysiology [40]. During the test, subjects were kept relaxed with comfortable light and temperature (26$28{ }^{\circ} \mathrm{C}$ ); the test was started after 5 min of previous adaptation. The apparatus used was an electromyography and evoked potential equipment (MedelecSynergy, Viasys Healthcare, Madison WI USA). Recording electrodes consisted of a pair of superficial electrodes: recording was carried out on the glabrous skin on the flat port-wine stain, and the reference was placed $2 \mathrm{~cm}$ away from the lesion. The ground electrode was proximal to the recording electrodes. Electrical stimulation was applied through superficial electrodes over the right median nerve. The stimulus was strong but tolerable (not noxious). The electrical stimulus was applied four times at irregular intervals of 30-60 s (stimulus duration: $0.1 \mathrm{~ms}$; intensity: $80 \mathrm{~mA}$ ) to avoid habituation, and SSR waves were obtained. SSR recordings were carried out in quadruplicates at the angiomas lesion sites and onto a contralateral healthy skin region in each patient.

The amplifier bandwidth was $0.1-100 \mathrm{~Hz}$. Responses were recorded on the skin with an impedance $<5 \mathrm{k} \Omega$. The mean latency and peak-to-peak amplitude were calculated and used for the following analyses.

\section{Statistical analysis}

For gene expression data, the statistically significant threshold originally set at $p=0.05$ was then corrected according to the Bonferroni correction for multiple comparisons, to take into account the multiple comparisons carried out. Therefore, the final corrected threshold was set at $\mathrm{p}<0.0005$ (value obtained from $0.05 / 90$ comparisons, for each investigated dataset).

The expression level of any given gene was considered to be significantly altered vs control when the significant $p$ value was matched in at least half-or in at least 1 -of the specific databases investigated for each tumor type. Namely, regarding the "at least half datasets" stringency level, the significant $p$ value had to be matched in at least 2 datasets out of the 4 investigated for bladder cancer; in at least 2 datasets out of the 4 studied for glioblastoma; in at least 2 datasets out of the 4 examined for melanoma; in at least 3 datasets out of the 5 investigated for invasive ductal breast carcinoma; in at least 4 datasets out of the 8 investigated for lung adenocarcinoma.

SSR was recorded four consecutive times for each patient on the diseased skin and four consecutive times on the healthy contralateral skin. Mean \pm SE was computed; mean latency and mean peak-to-peak amplitude recorded at the diseased-skin level were compared to measures obtained on the contralateral healthy control site. Paired t Student test was carried out, and statistical significance was set at $\mathrm{p}<0.05$. Normal distribution of SSR data was tested according to the D'Agostino-Pearson 
test and carried out by the GraphPad software. Data with normal distribution were analyzed with the paired $t$ test, while data with a not-normal distribution were analyzed with the non-parametric Wilcoxon match-paired signed ranked test.

\section{Results}

\section{Expression level of ion-channels genes in tumors}

The expression level of 90 ion-channels and ion-channels related genes (see Table 2 for the complete list) was analyzed in 3673 human biopsies of 5 histologically different solid tumors, namely: superficial bladder cancer, glioblastoma, melanoma, invasive ductal breast cancer, lung adenocarcinoma, as reported in Table 1 in more details.

Table 3 indicates the ion-channel families showing a significantly altered expression $(p<0.0005)$. For each cancer type, two columns are presented: the left-hand column (lighten) reports genes indicating a significantly modified expression in at least 1 -or less than half-of the investigated datasets. The right-hand column of each tumor type (shadowed) reports in bold all genes showing a significantly modified expression in at least half of the examined datasets (see criteria detailed in "Methods" section). All genes matching the shadowed columns criteria were found overexpressed. More in detail:

- Within the calcium channel, voltage-dependent family, expression of CACNAD1 gene was found significantly modified in superficial bladder cancer datasets, namely in Dyrskjot dataset $\left(p=4 \times 10^{-6}\right)$ and in Sanchez dataset $\left(p=5 \times 10^{-8}\right)$, with an average 3.7-fold increase vs. ctrls;

- Within the FXYD domain containing ion transport regulator family, expression of FXYD3 gene was found significantly modified in bladder cancer (Dyskjot dataset, $p=1 \times 10^{-6}$, Lee dataset, $p=3 \times 10^{-6}$ and Sanchez dataset, $p=6 \times 10^{-21}$ ) with an average 3.3-fold increase vs. ctrls. Furthermore, FXYD5 gene expression was found significantly modified in glioblastoma (in Lee dataset, $p=2 \times 10^{-5}$ and in Sun dataset, $p=1 \times 10^{-11}$ ) with an average 2.5 -fold increase vs. ctrls;

- Within the glutamate receptor, ionotropic family, expression of HTR3A gene was found significantly modified in 5 lung carcinoma datasets, namely in Beer dataset $\left(p=3 \times 10^{-8}\right)$, in Hou dataset $\left(p=7 \times 10^{-6}\right)$, in Okayama dataset $\left(p=2 \times 10^{-13}\right)$, in Selamat dataset $\left(p=1 \times 10^{-8}\right)$, and in Landi dataset $\left(p=8 \times 10^{-6}\right)$ with an average 5.08 fold increase vs ctrls;

- Within the potassium channel, voltage gated family, expression of three genes was found significantly modified in two cancer types. Namely, KCNE3 and
KCNE4 genes are modified in glioblastoma datasets. KCNE3 shows an average 5.3-fold increase vs. ctrls (in Lee dataset, $p=3 \times 10^{-10}$ and in Sun dataset, $\left.5 \times 10^{-9}\right)$. KCNE4 shows an average 2.9-fold increase vs ctrls in Lee dataset $\left(p=1 \times 10^{-8}\right)$ and in Sun dataset $\left(p=1 \times 10^{-13}\right)$. KCNN4 was found altered in nearly all lung carcinoma datasets, namely in Bhattacharjee dataset $\left(p=1 \times 10^{-6}\right)$, Stearman dataset $\left(p=3 \times 10^{-7}\right)$, Hou dataset $\left(p=3 \times 10^{-9}\right)$, Okayama dataset $\left(p=1 \times 10^{-8}\right)$, Selamat dataset $\left(p=2 \times 10^{-14}\right)$, Landi dataset $\left(p=2 \times 10^{-17}\right)$ and in Su dataset $\left(p=6 \times 10^{-8}\right)$ with an average 3.6-fold increase vs ctrls;

- Within the chloride channel family, expression of CLIC1 gene was found significantly modified in bladder cancer (in Lee dataset, $p=8 \times 10^{-8}$ and Sanchez dataset, $p=3 \times 10^{-5}$ ) with an average 1.5-fold increase vs. ctrls. CLIC1 is also significantly modified in glioblastoma (in Bredel dataset, $p=3 \times 10^{-7}$ and Sun dataset, $p=2 \times 10^{-23}$ ) with an average 5.7-fold increase vs. ctrls;

- Within the transient receptor potential cation channel family, expression of TRPM3 gene is altered in glioblastoma, i.e., in the Lee dataset $\left(p=5 \times 10^{-5}\right)$ and in the Sun dataset $\left(p=2 \times 10^{-5}\right)$ with an average 2.3-fold increase vs. ctrls.

Within the shadowed columns, glioblastoma appears to have the highest number of modified ion-channel genes (namely: FXYD5, KCNE3, KCNE4, CLIC1, TRPM3).

Melanoma and breast cancer show no genes in the shadowed columns. However, within the lighten columns, breast invasive ductal cancer and melanoma show significantly modified ion-channel genes from 13 families and 6 families, respectively.

\section{SSR recording in flat port-wine stains patients}

The above reported analyses demonstrated that the expression level of several ion-channels is significantly altered in several human cancer biopsies. Such tumors are histological different. However, they all present an altered vascular tree, due to the tumor neo-angiogenesis. We hence hypothesized that vascular alterations observed in several different cancer types may harbor, at least to a certain extent, the observed ion-channels expression modifications. According to these findings, we hypothesized that measuring ion-channel transport may represent a non-invasive technique to investigate alterations in tumor- as well non-tumor altered angiogenesis. In vivo analysis of ion transport in a vascular malformation, the clinical model was carried out. In fact, measuring in vivo ion-transport in tumor patients was considered ethically not acceptable; we were then 
Table 3 Genes reported show a significantly altered expression in each cancer type

\begin{tabular}{|c|c|c|c|c|c|c|c|c|c|c|}
\hline & \multicolumn{2}{|c|}{ Bladder cancer } & \multicolumn{2}{|c|}{ Breast cancer } & \multicolumn{2}{|c|}{ Glioblastoma } & \multicolumn{2}{|c|}{ Lung carcinoma } & \multicolumn{2}{|c|}{ Melanoma } \\
\hline 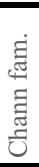 & $\begin{array}{c}\text { modified in } \\
\text { at least } 1 \\
\text { dataset }\end{array}$ & $\begin{array}{c}\text { modif. in at } \\
\text { least half } \\
\text { datasets }\end{array}$ & $\begin{array}{c}\text { modified in } \\
\text { at least } 1 \\
\text { dataset }\end{array}$ & $\begin{array}{c}\text { modif. } \\
\text { in at } \\
\text { least } \\
\text { half } \\
\text { datasets }\end{array}$ & $\begin{array}{c}\text { modified in } \\
\text { at least } 1 \\
\text { dataset }\end{array}$ & $\begin{array}{c}\text { modif. in } \\
\text { at least } \\
\text { half } \\
\text { datasets }\end{array}$ & $\begin{array}{c}\text { modified in } \\
\text { at least } 1 \\
\text { dataset }\end{array}$ & $\begin{array}{c}\text { modif. in } \\
\text { at least } \\
\text { half } \\
\text { datasets }\end{array}$ & $\begin{array}{c}\text { modif. in } \\
\text { at least } 1 \\
\text { dataset }\end{array}$ & $\begin{array}{c}\text { modif. } \\
\text { in at } \\
\text { least } \\
\text { half } \\
\text { datasets }\end{array}$ \\
\hline$A$ & & & $\begin{array}{l}\text { ACCN1 } \\
\text { ACCN3 }\end{array}$ & & & & $\mathrm{ACCN} 3$ & & & \\
\hline$B$ & CACNAD1 & CACNAD1 & & & $\begin{array}{l}\text { CACNA1A } \\
\text { CACNA1D } \\
\end{array}$ & & $\begin{array}{l}\text { CACNA1A } \\
\text { CACNA1B } \\
\end{array}$ & & & \\
\hline$C$ & $\begin{array}{l}\text { CATSPER1 } \\
\text { CATSPER2 }\end{array}$ & & $\begin{array}{l}\text { CATSPER1 } \\
\text { CATSPER3 }\end{array}$ & & & & CATSPER2 & & & \\
\hline$D$ & $\begin{array}{l}\text { FXYD5 } \\
\text { FXYD3 } \\
\end{array}$ & FXYD3 & $\begin{array}{l}\text { FXYD3 } \\
\text { FXYD5 } \\
\end{array}$ & & FXYD5 & FXYD5 & FXYD5 & & & \\
\hline$E$ & GABRB3 & & GABRB3 & & & & & & & \\
\hline$F$ & & & $\begin{array}{c}\text { GRIN2A } \\
\text { HTR3A }\end{array}$ & & & & HTR3A & HTR3A & \begin{tabular}{|l|} 
GRIA1 \\
GRIK1 \\
\end{tabular} & \\
\hline$G$ & $\begin{array}{l}\text { KCNN1 } \\
\text { KCNN4 }\end{array}$ & & $\begin{array}{c}\text { KCNE4 } \\
\text { KCNH2 } \\
\text { KCNH1 } \\
\text { KCNJ11 } \\
\text { KCNMA1 } \\
\text { KCNQ1 } \\
\text { KCNN2 }\end{array}$ & & $\begin{array}{c}\text { KCNE3 } \\
\text { KCNE4 } \\
\text { KCNMA1 } \\
\text { KCNQ1 } \\
\text { KCNRG }\end{array}$ & $\begin{array}{l}\text { KCNE3 } \\
\text { KCNE4 }\end{array}$ & $\begin{array}{l}\text { KCNN4 } \\
\text { KCNE4 } \\
\text { KCNJ11 } \\
\text { KCNQ1 } \\
\text { KCNN1 }\end{array}$ & KCNN4 & $\begin{array}{l}\text { KCNJ13 } \\
\text { KCNQ1 } \\
\text { KCNN2 }\end{array}$ & \\
\hline$H$ & & & $\begin{array}{l}\text { CHRNA1 } \\
\text { CHRNA2 } \\
\text { CHRNA3 } \\
\text { CHRNA5 }\end{array}$ & & CHRNA1 & & CHRNA5 & & & \\
\hline$I$ & $\begin{array}{l}\text { CLICN5 } \\
\text { CLIC1 }\end{array}$ & CLIC1 & & & CLIC1 & CLIC1 & CLCN5 & & CLCN1 & \\
\hline$L$ & CNGB3 & & & & & & CNGB3 & & & \\
\hline$N$ & & & & & NALCN & & & & & \\
\hline$O$ & & & $\begin{array}{l}\text { P2RX2 } \\
\text { P2RX4 }\end{array}$ & & $\mathrm{P} 2 \mathrm{RX} 4$ & & $\mathrm{P} 2 \mathrm{RX} 4$ & & \begin{tabular}{|l|} 
P2RX4 \\
P2RY13 \\
\end{tabular} & \\
\hline$Q$ & & & $\mathrm{RSC} 1 \mathrm{~A} 1$ & & & & & & & \\
\hline$R$ & & & $\begin{array}{l}\text { SCN1A } \\
\text { SCN3A }\end{array}$ & & $\mathrm{SCN} 2 \mathrm{~A}$ & & $\begin{array}{l}\text { SCN4A } \\
\text { SCN8A }\end{array}$ & & & \\
\hline$T$ & TPCN1 & & TPCN1 & & TPCN2 & & & & & \\
\hline$W$ & $\begin{array}{l}\text { TRPM2 } \\
\text { TRPM4 } \\
\text { TRPV4 }\end{array}$ & & $\begin{array}{l}\text { TRPM4 } \\
\text { TRPV1 } \\
\text { TRPV2 }\end{array}$ & & TRPM3 & TRPM3 & $\begin{array}{l}\text { TRPC2 } \\
\text { TRPM2 } \\
\text { TRPM4 } \\
\text { TRPV1 } \\
\text { TRPV4 } \\
\end{array}$ & & $\begin{array}{c}\text { TRPC4 } \\
\text { TRPM1 }\end{array}$ & \\
\hline$Z$ & AQP3 & & $\begin{array}{l}\text { AQP2 } \\
\text { AQP3 }\end{array}$ & & AQP4 & & & & AQP3 & \\
\hline
\end{tabular}

For each cancer type the lighten column reports ion-channels genes significantly modified in at least 1 dataset. The shadowed column reports ion-channels genes significantly modified in at least half of the investigated datasets. Channel family codes as in Table 2

Significance threshold: $p<0.0005$ (see "Methods" section)

forced to identify a non-tumor clinical condition showing clear vascular anomalies. The flat port-wine stains clinical model was approved by the Ethic Committee as a safe model to investigate Sympathetic Skin Responses and electrical signal transport, as the less invasive approach possible in the current study. SSR depends on $\mathrm{Ca}^{2+}, \mathrm{K}^{+}$, and $\mathrm{Cl}^{-}$channels found to be altered in Table 3 .
Therefore, 14 patients with flat port-wine stains diagnosis were consecutively recruited, namely eight female (mean age 27 years) and six male (mean age 29.1 years). SSR recordings were carried out in quadruplicates at the angiomas lesion sites and onto a contralateral healthy skin region in each patient. Statistical analysis was performed with paired tests as reported in Methods. 
Figure 1 shows the mean latency and means amplitude measured at diseased and healthy sites, expressed in $\mathrm{mV}$. A strong and significant reduction in both latency and peak-to-peak amplitude signals was observed in the diseased site as compared to the healthy site, in the whole patients population. When a gender-specific analysis was carried out, both latency and amplitude were strongly reduced in female patients, while latency was reduced in male, although in a not-significant manner.

\section{Ion channel expression in normal vessels as compared to tumor derived vessels}

Data reported in Table 3 and in Fig. 1 led us to hypothesize that ion channels genes may play a relevant role in cancers as well as in other pathological conditions of altered angiogenesis. To further support this hypothesis we investigated two human samples datasets available at GEO database. The first dataset (GSE41614) reports transcriptional profiling of tumor-associated blood vessels in human invasive bladder cancer samples. In such dataset the expression data were obtained on laser capture microdissected vessels isolated from normal bladder tissue or from tumor bladder tissues. Data from ten samples were analyzed, i.e., five normal samples vs five cancer samples.

The second dataset (GSE44115) reports gene expression data in OCT frozen human angiosarcoma compared to OCT frozen normal mesenchymal tissues. In this case 18 angiosarcoma samples were compared to four controls (two from skeletal muscle normal uninvolved tissue and two pooled RNA from normal tissues).

Tables 4 and 5 report the gene name, the $\log 2$ fold change, the $\mathrm{p}$ values adjusted according to the Benjamini and Hochberg false discovery rate methods, and the rank position (according to the by $\mathrm{p}$ value). Several genes, within the top 250 genes most significantly regulated, belong to ion channels families, either in bladder cancer blood vessels (9 genes, Table 4) and in angiosarcoma vessels (123 genes, Table 5$)$. Such data indicate that several ion channels may play a key role in the vessels within cancer tissues.

\section{Discussion}

It is widely known that nerves and vessels follow similar anatomical paths. Often nerves and vessels show an overlapping anatomy with overlapping branches and ramifications. Several molecular factors are reported to control their respective patterns and growth in a coordinated manner [41], including semaphorin, netrin and slit [42], all strongly regulated by $\mathrm{Ca}^{2+}, \mathrm{Na}^{+}$, and $\mathrm{Cl}^{-}$channels $[43,44]$. Thus, an architectural or functional modification of the ones may affect the architecture or function of the others. We, therefore, argued that unordered angiogenesis occurring in tumors and vascular malformations may associate to a corresponding unordered nerve formation and therefore to a measurable alteration of the electric stimulus transport. We hypothesized that (i) ion channels (which are known to regulate nerve- and

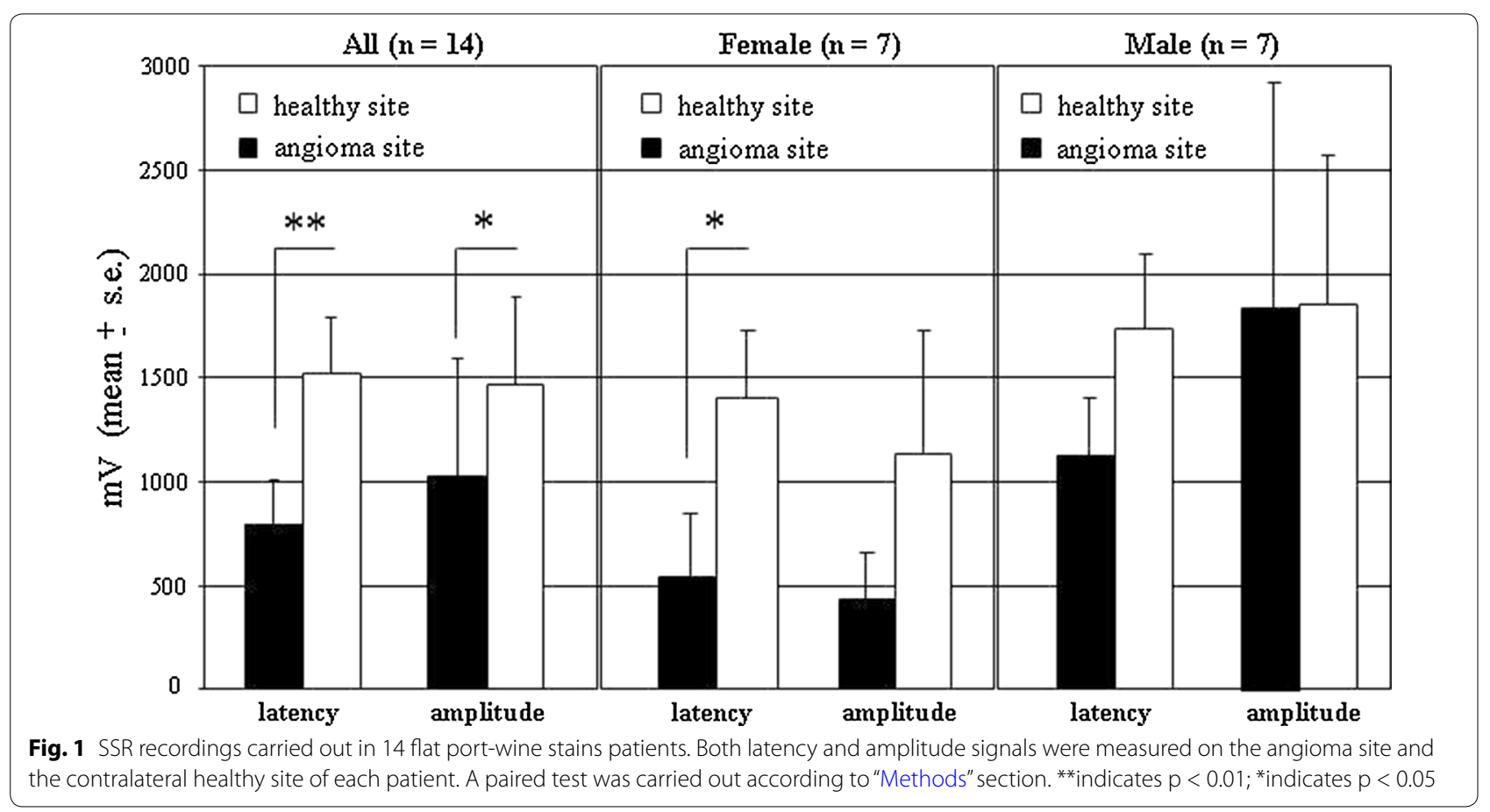


Table 4 lon channels genes most regulated in bladder cancer vessels vs control vessels

\begin{tabular}{|c|c|c|c|c|}
\hline $\begin{array}{l}\text { Rank position in the top } 250 \\
\text { (by } p \text { value) }\end{array}$ & Gene identifier & Gene name & Adjusted $p$ value* & $\log 2$ fold change \\
\hline 16th & KCNC4 & $\begin{array}{l}\text { Potassium voltage-gated channel subfamily } \mathrm{C} \text { mem- } \\
\text { ber } 4\end{array}$ & 0.009 & +0.507 \\
\hline 42th & KCNG4 & $\begin{array}{l}\text { Potassium voltage-gated channel modifier subfamily } \\
\text { G member } 4\end{array}$ & 0.01 & +0.415 \\
\hline 75th & VDAC3 & Voltage dependent anion channel 3 & 0.01 & -1.511 \\
\hline 90th & CRACR2B & Calcium release activated channel regulator $2 \mathrm{~B}$ & 0.01 & +0.472 \\
\hline 115th & KCNS2 & $\begin{array}{l}\text { Potassium voltage-gated channel modifier subfamily } \\
\text { S member } 2\end{array}$ & 0.01 & +0.637 \\
\hline 153th & SEC23B & $\begin{array}{l}\text { Sec23 homolog B, coat complex II component } \\
\text { (involved in vesicle trafficking) }\end{array}$ & 0.01 & -0.566 \\
\hline 173th & CBARP & CACN Beta subunit associated regulatory protein & 0.01 & +0.627 \\
\hline 218th & P2RX5 & Purinergic receptor P2X 5 (ligand-gated ion channel) & 0.01 & +0.403 \\
\hline 247 th & $\mathrm{SCN} 2 \mathrm{~B}$ & Sodium voltage-gated channel beta subunit 2 & 0.02 & +0.487 \\
\hline
\end{tabular}

* According to the Benjamini and Hochberg false discovery rate method

Data from Geo dataset GSE41614, available at http://www.ncbi.nlm.nih.gov/geo/query/acc.cgi?acc=GSE41614)

Table 5 lon channels genes most regulated in angiosarcoma vs controls

\begin{tabular}{|c|c|c|c|c|}
\hline $\begin{array}{l}\text { Rank position in the top } \\
250 \text { (by value) }\end{array}$ & Gene identifier & Gene name & Adjusted $p$ value* & $\log 2$ fold change \\
\hline 3th & KCNJ16 & Potassium voltage-gated channel subfamily J member 16 & 0.0000003 & +6.673 \\
\hline 41 th & CLCNKA & Chloride voltage-gated channel Ka & 0.001 & +3.516 \\
\hline 52 th & HCN2 & $\begin{array}{l}\text { Hyperpolarization activated cyclic nucleotide gated potas- } \\
\text { sium channel } 2\end{array}$ & 0.001 & +2.099 \\
\hline 53th & KCNQ2 & Potassium voltage-gated channel subfamily Q member 2 & 0.001 & +1.276 \\
\hline 61 th & FXYD4 & FXYD domain containing ion transport regulator 4 & 0.0009 & +6.247 \\
\hline 75th & CRACR2B & Calcium release activated channel regulator $2 \mathrm{~B}$ & 0.002 & +1.117 \\
\hline 104th & AQP10 & Aquaporin 10 & 0.004 & +2.096 \\
\hline 125th & KCNJ15 & Potassium voltage-gated channel subfamily J member 15 & 0.004 & +3.203 \\
\hline 147th & KCNK12 & $\begin{array}{l}\text { Potassium two pore domain channel subfamily } \mathrm{K} \text { member } \\
12\end{array}$ & 0.004 & +2.008 \\
\hline 153th & FXYD2 & FXYD domain containing ion transport regulator 2 & 0.005 & +2.596 \\
\hline 167 th & KCNJ1 & Potassium voltage-gated channel subfamily J member 1 & 0.01 & +3.369 \\
\hline 250th & AQP2 & Aquaporin 2 & 0.01 & +8.359 \\
\hline
\end{tabular}

* According to the Benjamini and Hochberg false discovery rate method

Data from Geo dataset GSE44115, available at http://www.ncbi.nlm.nih.gov/geo/query/acc.cgi?acc=GSE44115)

vessel- formation) may show altered expression in tumors and (ii) SSR recording in vascular malformations patients may unreveal a clinical non-invasive sign of the unordered vessels formation.

The expression level of members of several ion-channel families was found significantly modified in histologically different human cancer biopsies, according to the measures reported in Oncomine database, in an almost 4000 patients-vs-controls group. While several genes were found significantly modified $(\mathrm{p}<0.0005)$ in at least one human dataset, we limit here the discussion to the genes reported in the shadowed columns of Table 3 selected according to highly stringent criteria, i.e. to the ion-channel genes found altered in at least half of the investigated databases of each tumor. We report in the current study that such genes show an increased expression in cancer vs. ctrls samples and have in most cases a definite role in vascular biology and/or cancer setup/progression or nervous system biology.

CACNA1D, a calcium related transporter gene, shows an average 3.75-fold increased expression in superficial bladder cancer datasets. No reports are present in 
literature referring CACNA1D direct link to bladder cancer. Nevertheless, some studies relate its expression- and methylation-level to prostate cancer [45, 46], indicating CACNA1D as a possible regulator of prostate cancer aggressiveness [47], or refer it to CNS disorders [48], diabetes [49] or calcium level within the vessels [50].

FXYD3 shows a 3.3 average fold increase expression in bladder cancer. It encodes a cell membrane protein regulating ion-pumps and ion-channels function and is known to have a role in tumor progression. Its activity is related to glucose and $\mathrm{Cl}^{-}$ions and has been indicated as a possible biomarker in bladder cancer $[51,52]$ as well as other cancers including breast [53], colorectal cancer [54], endometrial cancer [55] and intrahepatic cholangiocarcinoma [56].

FXYD5 is a transmembrane auxiliary subunit of the $\mathrm{Na}^{+}-\mathrm{K}^{+}$-ATPase; it shows a 2.5 -fold increase in glioblastoma. No direct link with glioblastoma has been reported to date, however it has been found up-regulated in adamantinomatous craniopharyngiomas in children [57] and other members of the FXYD family are known to be associated with different cancer types such as urothelial carcinoma [58], esophageal squamous cell carcinoma [59] and cholangiocarcinoma [60]. FXYD channels are involved in the anti-oxidative stress in vascular smooth muscle, thus controlling the vascular tone [61] and blood pressure [62]. Most interestingly, expression of FXYD2 and FXYD4 genes is modified in angiosarcoma vs control human samples (Table 5).

The expression of serotonin receptor HTR3A was found increased by fivefold in lung carcinoma; no direct link has been reported between HTR3A and lung adenocarcinoma, yet; however, nucleotide polymorphisms of this gene have been related to opioid- or nausea/vomiting signaling pathways in cancer patients [63] and to bowel syndrome [64]. HTR3 is the only ligand-gated ion channel among the serotonin receptors, and it has been associated with neurological disorders such as depression [65] or schizophrenia [66]. Most interestingly about the current study, HTR3A acts as a ligand-gated ion channel neurotransmitter, and causes fast, depolarizing responses in neurons (http://www.genecards.org/cgi-bin/carddisp. pl?gene $=$ HTR3A). It is up-regulated in rosacea, i.e., a chronic inflammatory skin disease often showing telangiectasias in the erythematotelangiectatic form (ETR) [67].

Within the potassium intermediate/small conductance calcium-activated channels, expression of 3 genes (namely KCNE3, KCNE4, KCNN4) has been found altered in the current study, namely in glioblastoma and lung adenocarcinoma. While no direct evidence relate KCNE3 or KCNE4 to glioblastoma, KCNE4 is most abundantly expressed in brain [68]; it exerts functions such as controlling the neuronal firing rate, the synaptic transmission [69] and the T-lymphocytes maturation [70] and it is known to regulate K-channels in vascular smooth muscle [71] and more in general neuronal excitability. Furthermore, KCNN4 single-nucleotide polymorphisms have been related to myocardial infarction [72] Most interestingly, KCNN4 has been linked to vascular cells proliferation [73]. Notably, expression of several potassium channels is modified in bladder cancer vessels vs controls (KCNC4, KCNG4, KCNS2, see Table 4) and in angiosarcoma vs controls (namely KCNJ16, KCNQ2, KCNJ15, KCNJ12, KCNJ1, see Table 5).

Within the Cl- intracellular channels, CLIC1 expression was found altered in bladder cancer and glioblastoma. CLIC1 has been previously found up-regulated in glioblastoma [74], it is involved in different tumors and acts as an oncogene in pancreatic cancer [75], and has been indicated as a possible cancer biomarker [76]. Interestingly, CLIC1 has recently shown a key role in angiogenesis control in combination with integrins [77, 78]. Interestingly, expression of one $\mathrm{Cl}^{-}$channel (namely CLCNKA) is strongly modified in angiosarcoma vs controls (see Table 5).

Within the transient receptor potential cation channels, TRPM3 gene expression was found increased in glioblastoma by 2.3 -fold. Its expression has been previously found increased in glioblastoma [79] and is known to exhibit mechanosensitivity contributing to vascular and cardiac functions [80].

SSR is under the direct control of $\mathrm{Ca}^{2+}, \mathrm{K}^{-}, \mathrm{Cl}^{-}$ion channels and strictly depends on the sympathetic autonomous nerve function. In the current study, several ion channels related to the $\mathrm{Ca}^{2+}, \mathrm{K}^{+}$, and $\mathrm{Cl}^{-}$have relevant, and significantly increased expression in different human cancers and SSR was found strongly altered in human vascular malformations. SSR has been previously indicated as a possible useful diagnostic technique in CNS pathologies [81, 82], as well as fibromyalgia [83] and diabetes [84]. Further, autonomic nerve development and function has been recently shown to play a key role in prostate cancer progression [85]. Thus, given the known role of several ion channels in the tumor, nerve, and vascular biology, we hypothesize that the altered SSR observed in vascular skin malformations, and the observed altered ion-channel gene-expression in several tumors may represent phenomena related to the unordered nerve- and vessel formation, common to tumorrelated and non-tumor-related vascular anomalies.

SSR recording gave more significant results in female while in male the trend was present but with no statistical significance. Such difference may be related to a different transport of electrical stimuli in the female skin, which appears evident at both healthy (white boxes in Fig. 1) and diseased sites (black boxes in Fig. 1), as 
compared to male. A gender-related difference in the skin thickness may underlie, at least in part, such observation likely associated with the skin thickness and water retention induced by the menstrual phases and the hormonal status in females.

In conclusion, data reported in the current study allowed us to conclude that ion-channel expression and function may be strongly affected in pathological conditions where vessels' (and nerves') architecture is altered. SSR measurement may thus represent a non-invasive useful tool to investigate vascular skin alterations in both tumor and non-tumor conditions.

\section{Conclusions}

The present study reports for the first time a detailed analysis of the expression level of 90 ion-channel genes in 3673 biopsies form humans affected by solid tumors and from healthy controls. At least ten genes from different ion-channels families were found firmly and significantly up-regulated in histologically different tumors having in common the underlying unordered tumor neo-angiogenesis (Table 3). Moreover, expression of at least 20 ion channels has been found to be strongly modified in cancer associated vessels vs controls (Tables 4,5 ). The sympathetic skin responses (SSR), an electrical feature closely related to the ion-channels activity, was then measured in vivo and was found strongly modified in the skin of patients affected by the flat port-wine stains vascular malformation. The present study indicates that modified expression and activity of ion channels is likely related to vascular alteration, in both tumor and non-tumor conditions, and suggests the non invasive technique SSR as a simple, useful tool to investigate skin vascular anomalies.

\section{Authors' contributions}

$A B, D D, E M N, A F$ : design of the study; data collection; data interpretation; writing. FP: data interpretation. All authors read and approved the final manuscript.

\section{Author details \\ ${ }^{1}$ Department of Neurology and Psychiatry, Sapienza University, Rome, Italy. ${ }^{2}$ Istituto Dermopatico dell'Immacolata, IDI-IRCCS, Fondazione Luigi Maria Monti, via Monti di Creta 104, 00167 Rome, Italy.}

\section{Competing interests}

The authors declare that they have no competing interests.

\section{Ethics approval and consent to participate}

The study was approved by the institutional review board of IDI-IRCCS Hospital, Rome (IDI Ethic Committee 2011, n. 363). All patients signed an informed consent to participate in the study.

\section{Funding}

This study has been partially supported by Ministry of Health, Ric. Cor. 2013-2014, Line 3.4 to AF.

Received: 31 May 2016 Accepted: 21 September 2016

Published online: 04 October 2016
References

1. Blackiston DJ, McLaughlin KA, Levin M. Bioelectric controls of cell proliferation: ion channels, membrane voltage and the cell cycle. Cell Cycle. 2009;8:3527-36.

2. Kunzelmann K. Ion channels in regulated cell death. Cell Mol Life Sci. 2016;73(11-12):2387-403.

3. Alfarouk KO. Tumor metabolism, cancer cell transporters, and microenvironmental resistance. J Enzyme Inhib Med Chem. 2016;31:859-66. doi:10.3109/14756366.2016.1140753.

4. Enomoto K, Cossu MF, Maeno T, Edwards C, Oka T. Involvement of the $\mathrm{Ca}^{2}+$-dependent $\mathrm{K}+$ channel activity in the hyperpolarizing response induced by epidermal growth factor in mammary epithelial cells. FEBS Lett. 1986;203:181-4.

5. Campbell TM, Main MJ, Fitzgerald EM. Functional expression of the voltage-gated $\mathrm{Na}^{+}$-channel Nav1.7 is necessary for EGF-mediated invasion in human non-small cell lung cancer cells. J Cell Sci. 2013;126:4939-49.

6. Frede J, Fraser SP, Oskay-Özcelik G, Hong Y, Ioana Braicu E, Sehouli J, Gabra H, Djamgoz MBA. Ovarian cancer: ion channel and aquaporin expression as novel targets of clinical potential. Eur J Cancer. 2013:49:2331-44.

7. Cone CD. Unified theory on the basic mechanism of normal mitotic control and oncogenesis. JTheor Biol. 1971;30:151-81.

8. Cone CD. Electroosmotic interactions accompanying mitosis initation in sarcoma cells in vitro. Trans NY Acad Sci. 1969;31:404-27.

9. Bränström R, Chang Y-M, Kasparian N, Affleck P, Tibben A, Aspinwall LG, Azizi E, Baron-Epel O, Battistuzzi L, Bruno W, Chan M, Cuellar F, et al. Melanoma risk factors, perceived threat and intentional tanning: an international online survey. Eur J Cancer Prev. 2010;19:216-26.

10. Wang E, Yin Y, Zhao M, Forrester JV, McCaig CD. Physiological electric fields control the G1/S phase cell cycle checkpoint to inhibit endothelial cell proliferation. FASEB J. 2003;17:458-60.

11. Zhao M, Song B, Pu J, Wada T, Reid B, Tai G, Wang F, Guo A, Walczysko P, Gu Y, Sasaki T, Suzuki A, et al. Electrical signals control wound healing through phosphatidylinositol-3-OH kinase-gamma and PTEN. Nature. 2006;442:457-60.

12. Kunzelmann K. Ion channels and cancer. J Membr Biol. 2005;205:159-73.

13. Thongon N, Ketkeaw P, Nuekchob C. The roles of acid-sensing ion channel $1 \mathrm{a}$ and ovarian cancer $\mathrm{G}$ protein-coupled receptor 1 on passive $\mathrm{Mg}^{2}+$ transport across intestinal epithelium-like Caco-2 monolayers. J Physiol Sci. 2014;64:129-39.

14. Ko J-H, Ko EA, Gu W, Lim I, Bang H, Zhou T. Expression profiling of ion channel genes predicts clinical outcome in breast cancer. Mol Cancer. 2013:12:106.

15. Han X, Xi L, Wang H, Huang X, Ma X, Han Z, Wu P, Ma X, Lu Y, Wang G, Zhou J, Ma D. The potassium ion channel opener NS1619 inhibits proliferation and induces apoptosis in A2780 ovarian cancer cells. Biochem Biophys Res Commun. 2008;375:205-9.

16. D'Arcangelo D, Silletta MG, Di Francesco AL, Bonfitto N, Di Cerbo A, Falasca M, Corda D. Physiological concentrations of thyrotropin increase cytosolic calcium levels in primary cultures of human thyroid cells. J Clin Endocrinol Metab. 1995;80:1136-43.

17. Martial S. Involvement of ion channels and transporters in carcinoma angiogenesis and metastasis. Am J Physiol Cell Physiol. 2016. doi:10.1152/ajpcell.00218.2015.

18. Shim JH, Lim JW, Kim BK, Park SJ, Kim SW, Choi TH. KCl mediates K(+) channel-activated mitogen-activated protein kinases signaling in wound healing. Arch Plast Surg. 2015;42:11-9.

19. Thoppil RJ, Cappelli HC, Adapala RK, Kanugula AK, Paruchuri S, Thodeti CK. TRPV4 channels regulate tumor angiogenesis via modulation of Rho/Rho kinase pathway. Oncotarget. 2016;7:25849-61.

20. Adapala RK, Thoppil RJ, Ghosh K, Cappelli HC, Dudley AC, Paruchuri S, Keshamouni V, Klagsbrun M, Meszaros JG, Chilian WM, Ingber DE, Thodeti CK. Activation of mechanosensitive ion channel TRPV4 normalizes tumor vasculature and improves cancer therapy. Oncogene. 2016:35:314-22.

21. Xu T, Fan Z, Li W, Dietel B, Wu Y, Beckmann MW, Wrosch JK, Buchfelder M, Eyupoglu IY, Cao Z, Savaskan NE. Identification of two novel chlorotoxin derivatives CA4 and CTX-23 with chemotherapeutic and anti-angiogenic potential. Sci Rep. 2016;6:19799. 
22. Crottès D, Rapetti-Mauss R, Alcaraz-Perez F, Tichet M, Gariano G, Martial S, Guizouarn H, Pellissier B, Loubat A, Popa A, Paquet A, Presta M, et al. SIGMAR1 regulates membrane electrical activity in response to extracellular matrix stimulation to drive cancer cell invasiveness. Cancer Res. 2016;76:607-18

23. Lian CG, Sholl LM, Zakka LR, Liu C, Xu S, Stanek E, Garcia E, Jia Y, MacConaill LE, Murphy GF, Waner M, et al. Novel genetic mutations in a sporadic port-wine stain. JAMA Dermatol. 2014;150:1336-40.

24. Vetrugno R, Liguori R, Cortelli P, Montagna P. Sympathetic skin response: basic mechanisms and clinical applications. Clin Auton Res. 2003;13:256-70.

25. Maselli RA, Jaspan JB, Soliven BC, Green AJ, Spire JP, Arnason BG. Comparison of sympathetic skin response with quantitative sudomotor axon reflex test in diabetic neuropathy. Muscle Nerve. 1989;12:420-3.

26. Niakan E, Harati Y. Sympathetic skin response in diabetic peripheral neuropathy. Muscle Nerve. 1988;11:261-4.

27. Goizueta-San Martín G, Gutiérrez-Gutiérrez G, Godoy-Tundidor H, Mingorance-Goizueta B, Mingorance-Goizueta C, Vega-Piris L, Gutiérrez-Rivas E. Sympathetic skin response: reference data for 100 normal subjects. Rev Neurol. 2013;56:321-6.

28. Cappuzzello C, Di Vito L, Melchionna R, Melillo G, Silvestri L, Cesareo E, Crea F, Liuzzo G, Facchiano A, Capogrossi MC, Napolitano M. Increase of plasma IL-9 and decrease of plasma IL-5, IL-7, and IFN- $\gamma$ in patients with chronic heart failure. J Transl Med. 2011:9:28.

29. Buttari B, Segoni L, Profumo E, D’Arcangelo D, Rossi S, Facchiano F, Businaro R, luliano L, Rigano R. 7-Oxo-cholesterol potentiates proinflammatory signaling in human M1 and M2 macrophages. Biochem Pharmacol. 2013;86:130-7

30. Aguzzi MS, Facchiano F, Ribatti D, Gaeta R, Casadio R, Rossi I, Capogrossi MC, Facchiano A. A novel RGDS-analog inhibits angiogenesis in vitro and in vivo. Biochem Biophys Res Commun. 2004;321:809-14

31. D'Arcangelo D, Nicodemi EM, Rossi S, Giampietri C, Facchiano F, Facchiano A. Identification of serum regression signs in infantile hemangioma. PLoS One. 2014;9:e88545.

32. Faraone D, Aguzzi MS, Toietta G, Facchiano AM, Facchiano F, Magenta A, Martelli F, Truffa S, Cesareo E, Ribatti D, Capogrossi MC, Facchiano A Platelet-derived growth factor-receptor a strongly inhibits melanoma growth in vitro and in vivo. Neoplasia. 2009;11:732

33. Hernández-Bule ML, Paíno CL, Trillo MÁ, Úbeda A. Electric stimulation at $448 \mathrm{kHz}$ promotes proliferation of human mesenchymal stem cells. Cell Physiol Biochem. 2014;34:1741-55.

34. Yuan X, Arkonac DE, Chao PG, Vunjak-Novakovic G. Electrical stimulation enhances cell migration and integrative repair in the meniscus. Sci Rep. 2014:4:3674.

35. Chang K-A, Kim JW, Kim JA, Lee SE, Lee S, Kim S, Suh WH, Kim H-S, Kwon S, Kim SJ, Suh Y-H. Biphasic electrical currents stimulation promotes both proliferation and differentiation of fetal neural stem cells. PLoS One. 2011;6:e18738.

36. Kim IS, Song JK, Zhang YL, Lee TH, Cho TH, Song YM, Kim DK, Kim SJ, Hwang SJ. Biphasic electric current stimulates proliferation and induces VEGF production in osteoblasts. Biochim Biophys Acta. 2006;1763:907-16

37. Gu X, Fu J, Bai J, Zhang C, Wang J, Pan W. Low-frequency electrical stimulation induces the proliferation and differentiation of peripheral blood stem cells into Schwann cells. Am J Med Sci. 2015:349:157-61.

38. Lim J-H, McCullen SD, Piedrahita JA, Loboa EG, Olby NJ. Alternating current electric fields of varying frequencies: effects on proliferation and differentiation of porcine neural progenitor cells. Cell Reprogr. 2013:15:405-12

39. Collard J-F, Lazar C, Nowé A, Hinsenkamp M. Statistical validation of the acceleration of the differentiation at the expense of the proliferation in human epidermal cells exposed to extremely low frequency electric fields. Prog Biophys Mol Biol. 2013;111:37-45

40. Claus D, Schondorf R. Sympathetic skin response. The international federation of clinical neurophysiology. Electroencephalogr Clin Neurophysiol Suppl. 1999;52:277-82

41. Shi N, Chen S-Y. From nerve to blood vessel: a new role of Olfm2 in smooth muscle differentiation from human embryonic stem cellderived mesenchymal cells. J Biomed Res. 2015;29:261-3.

42. Melani $M$, Weinstein BM. Common factors regulating patterning of the nervous and vascular systems. Annu Rev Cell Dev Biol. 2010;26:639-65.
43. Behar O, Mizuno K, Badminton M, Woolf CJ. Semaphorin 3A growth cone collapse requires a sequence homologous to tarantula hanatoxin. Proc Natl Acad Sci USA. 1999;96:13501-5.

44. Nishiyama M, von Schimmelmann MJ, Togashi K, Findley WM, Hong K. Membrane potential shifts caused by diffusible guidance signals direct growth-cone turning. Nat Neurosci. 2008;11:762-71.

45. Roudier MP, Winters BR, Coleman I, Lam H-M, Zhang X, Coleman R, Chéry L, True LD, Higano CS, Montgomery B, Lange PH, Snyder LA, et al. Characterizing the molecular features of ERG-positive tumors in primary and castration resistant prostate cancer. Prostate. 2016;76:810-22.

46. Geybels MS, Alumkal JJ, Luedeke M, Rinckleb A, Zhao S, Shui IM, Bibikova M, Klotzle B, van den Brandt PA, Ostrander EA, Fan J-B, Feng $Z$, et al. Epigenomic profiling of prostate cancer identifies differentially methylated genes in TMPRSS2:ERG fusion-positive versus fusion-negative tumors. Clin Epigenetics. 2015;7:128.

47. Zhu G, Liu Z, Epstein J, Davis C, Christudass CS, Carter HB, Landis P, Zhang H, Chung J-Y, Hewitt SM, Miller MC, Veltri RW. A novel quantitative multiplex tissue immunoblotting for biomarkers predicts a prostate cancer aggressive phenotype. Cancer Epidemiol Biomarkers Prev. 2015:24:1864-72

48. Pinggera A, Striessnig J. Cav 1.3 (CACNA1D) L-type Ca $\left(2^{+}\right)$channel dysfunction in CNS disorders. J Physiol. 2016. doi:10.1113/JP270672.

49. Reinbothe TM, Alkayyali S, Ahlqvist E, Tuomi T, Isomaa B, Lyssenko $\mathrm{V}$, Renström E. The human L-type calcium channel Cav1.3 regulates insulin release and polymorphisms in CACNA1D associate with type 2 diabetes. Diabetologia. 2013;56:340-9.

50. Navedo MF, Amberg GC, Westenbroek RE, Sinnegger-Brauns MJ, Catterall WA, Striessnig J, Santana LF. Ca(v)1.3 channels produce persistent calcium sparklets, but $\mathrm{Ca}(\mathrm{v}) 1.2$ channels are responsible for sparklets in mouse arterial smooth muscle. Am J Physiol Heart Circ Physiol. 2007:293:H1359-70.

51. Ramírez-Backhaus M, Fernández-Serra A, Rubio-Briones J, Cruz Garcia P, Calatrava A, Garcia Casado Z, Casanova Salas I, Rubio L, Solsona E, López-Guerrero JA. External validation of FXYD3 and KRT20 as predictive biomarkers for the presence of micrometastasis in muscle invasive bladder cancer lymph nodes. Actas Urol Españolas. 2015;39:473-81.

52. Gazquez C, Ribal MJ, Marín-Aguilera M, Kayed H, Fernández PL, Mengual $L$, Alcaraz A. Biomarkers vs conventional histological analysis to detect lymph node micrometastases in bladder cancer: a real improvement? BJU Int. 2012;110:1310-6.

53. Liu C-C, Teh R, Mozar CA, Baxter RC, Rasmussen HH. Silencing overexpression of FXYD3 protein in breast cancer cells amplifies effects of doxorubicin and $\mathrm{\gamma}$-radiation on $\mathrm{Na}(+) / \mathrm{K}(+)$-ATPase and cell survival. Breast Cancer Res Treat. 2016;155:203-13.

54. Simmer F, Venderbosch S, Dijkstra JR, Vink-Börger EM, Faber C, Mekenkamp LJ, Koopman M, De Haan AF, Punt CJ, Nagtegaal ID. MicroRNA-143 is a putative predictive factor for the response to fluoropyrimidine-based chemotherapy in patients with metastatic colorectal cancer. Oncotarget. 2015;6:22996-3007.

55. Li Y, Zhang X, Xu S, Ge J, Liu J, Li L, Fang G, Meng Y, Zhang H, Sun X. Expression and clinical significance of FXYD3 in endometrial cancer. Oncol Lett. 2014;8:517-22

56. Subrungruanga I, Thawornkunob C, Chawalitchewinkoon-Petmitrc P, Pairojkul C, Wongkham S, Petmitrb S. Gene expression profiling of intrahepatic cholangiocarcinoma. Asian Pac J Cancer Prev. 2013;14:557-63.

57. Gong J, Zhang H, Xing S, Li C, Ma Z, Jia G, Hu W. High expression levels of CXCL12 and CXCR4 predict recurrence of adamanti-nomatous craniopharyngiomas in children. Cancer Biomark. 2014;14:241-51.

58. Zhang Z, Pang S-T, Kasper KA, Luan C, Wondergem B, Lin F, Chuang C-K, Teh BT, Yang XJ. FXYD3: a promising biomarker for urothelial carcinoma. Biomark Insights. 2011;6:17-26.

59. Zhu Z-L, Yan B-Y, Zhang Y, Yang Y-H, Wang M-W, Zentgraf $H$, Zhang X-H, Sun X-F. Overexpression of FXYD-3 is involved in the tumorigenesis and development of esophageal squamous cell carcinoma. Dis Markers. 2013:35:195-202.

60. Chen X, Sun M, Hu Y, Zhang H, Wang Z, Zhou N, Yan X. FXYD6 is a new biomarker of cholangiocarcinoma. Oncol Lett. 2014;7:393-8.

61. Liu C-C, Karimi Galougahi K, Weisbrod RM, Hansen T, Ravaie R, Nunez A, Liu YB, Fry N, Garcia A, Hamilton EJ, Sweadner KJ, Cohen RA, et al. Oxidative inhibition of the vascular $\mathrm{Na}+-\mathrm{K}+$ pump via NADPH 
oxidase-dependent $\beta 1$-subunit glutathionylation: implications for angiotensin II-induced vascular dysfunction. Free Radic Biol Med. 2013;65:563-72.

62. Huang X, Wang B, Yang D, Shi X, Hong J, Wang S, Dai X, Zhou X, Geng Y-J. Reduced expression of FXYD domain containing ion transport regulator 5 in association with hypertension. Int J Mol Med. 2012;29:231-8.

63. Laugsand EA, Fladvad T, Skorpen F, Maltoni M, Kaasa S, Fayers P, Klepstad P. Clinical and genetic factors associated with nausea and vomiting in cancer patients receiving opioids. Eur J Cancer. 2011:47:1682-91.

64. Gu Q-Y, Zhang J, Feng Y-C, Dai G-R, Du W-P. Association of genetic polymorphisms in HTR3A and HTR3E with diarrhea predominant irritable bowel syndrome. Int J Clin Exp Med. 2015;8:4581-5.

65. Gatt JM, Williams LM, Schofield PR, Dobson-Stone C, Paul RH, Grieve SM, Clark CR, Gordon E, Nemeroff CB. Impact of the HTR3A gene with early life trauma on emotional brain networks and depressed mood. Depress Anxiety. 2010;27:752-9.

66. Schuhmacher A, Mössner R, Quednow BB, Kühn K-U, Wagner M, Cvetanovska G, Rujescu D, Zill P, Möller H-J, Rietschel M, Franke P, Wölwer W, et al. Influence of 5-HT3 receptor subunit genes HTR3A, HTR3B, HTR3C, HTR3D and HTR3E on treatment response to antipsychotics in schizophrenia. Pharmacogenet Genomics. 2009;19:843-51.

67. Steinhoff M, Schauber J, Leyden JJ. New insights into rosacea pathophysiology: a review of recent findings. J Am Acad Dermatol. 2013;69:S15-26.

68. Manderfield LJ, George AL. KCNE4 can co-associate with the I(Ks) (KCNQ1-KCNE1) channel complex. FEBS J. 2008;275:1336-49.

69. Grunnet M, Rasmussen HB, Hay-Schmidt A, Rosenstierne M, Klaerke DA, Olesen S-P, Jespersen T. KCNE4 is an inhibitory subunit to Kv1.1 and Kv1.3 potassium channels. Biophys J. 2003;85:1525-37.

70. Grissmer S, Dethlefs B, Wasmuth JJ, Goldin AL, Gutman GA, Cahalan MD, Chandy KG. Expression and chromosomal localization of a lymphocyte K+ channel gene. Proc Natl Acad Sci USA. 1990;87:9411-5.

71. Jepps TA, Carr G, Lundegaard PR, Olesen S-P, Greenwood IA. Fundamental role for the KCNE4 ancillary subunit in KV7.4 regulation of arterial tone. J Physiol. 2015;593:5325-40.

72. Yamaguchi M, Nakayama T, Fu Z, Naganuma T, Sato N, Soma M, Doba N, Hinohara S, Morita A, Mizutani T. Relationship between haplotypes of KCNN4 gene and susceptibility to human vascular diseases in Japanese. Med Sci Monit. 2009;15:CR389-97.

73. Cheong A, Bingham AJ, Li J, Kumar B, Sukumar P, Munsch C, Buckley NJ, Neylon CB, Porter KE, Beech DJ, Wood IC. Downregulated REST transcription factor is a switch enabling critical potassium channe expression and cell proliferation. Mol Cell. 2005;20:45-52.

74. Setti M, Osti D, Richichi C, Ortensi B, Del Bene M, Fornasari L, Beznoussenko G, Mironov A, Rappa G, Cuomo A, Faretta M, Bonaldi T, et al. Extracellular vesicle-mediated transfer of CLIC1 protein is a novel mechanism for the regulation of glioblastoma growth. Oncotarget. 2015;6:31413-27.

75. Lu J, Dong Q, Zhang B, Wang X, Ye B, Zhang F, Song X, Gao G, Mu J, Wang Z, Ma F, Gu J. Chloride intracellular channel 1 (CLIC1) is activated and functions as an oncogene in pancreatic cancer. Med Oncol. 2015;32:616.

76. Peretti M, Angelini M, Savalli N, Florio T, Yuspa SH, Mazzanti M. Chloride channels in cancer: focus on chloride intracellular channel 1 and 4 (CLIC1 AND CLIC4) proteins in tumor development and as novel therapeutic targets. Biochim Biophys Acta. 2015;1848:2523-31.

77. Knowles LM, Malik G, Hood BL, Conrads TP, Pilch J. CLT1 targets angiogenic endothelium through CLIC1 and fibronectin. Angiogenesis. 2012;15:115-29.

78. Tung JJ, Kitajewski J. Chloride intracellular channel 1 functions in endothelial cell growth and migration. J Angiogenes Res. 2010;2:23.

79. Alptekin M, Eroglu S, Tutar E, Sencan S, Geyik MA, Ulasli M, Demiryurek AT, Camci C. Gene expressions of TRP channels in glioblastoma multiforme and relation with survival. Tumour Biol. 2015;36:9209-13.

80. Inoue R, Jian Z, Kawarabayashi Y. Mechanosensitive TRP channels in cardiovascular pathophysiology. Pharmacol Ther. 2009;123:371-85.

81. Negami M, Maruta T, Takeda C, Adachi Y, Yoshikawa H. Sympathetic skin response and heart rate variability as diagnostic tools for the differential diagnosis of Lewy body dementia and Alzheimer's disease: a diagnostic test study. BMJ Open. 2013;3:e001796.
82. Nazliel B, Irkeç C, Koçer B. The roles of blink reflex and sympathetic skin response in multiple sclerosis diagnosis. Mult Scler. 2002;8:500-4.

83. Ozkan O, Yildiz M, Arslan E, Yildiz S, Bilgin S, Akkus S, Koyuncuoglu HR, Koklukaya E. A study on the effects of sympathetic skin response parameters in diagnosis of fibromyalgia using artificial neural networks. J Med Syst. 2016:40:54.

84. Ono S, Nishijo Y, Oishi M, Mizutani T. Comparison of the utility of sympathetic skin response and current perception threshold examinations with conventional examinations for the early electrophysiological diagnosis of diabetic polyneuropathy. Electromyogr Clin Neurophysiol. 2005:46:401-7.

85. Magnon C, Hall SJ, Lin J, Xue X, Gerber L, Freedland SJ, Frenette PS. Autonomic nerve development contributes to prostate cancer progression. Science. 2013;341:1236361.

86. Dyrskjøt L, Kruhøffer M, Thykjaer T, Marcussen N, Jensen JL, Møller K, Ørntoft TF. Gene expression in the urinary bladder: a common carcinoma in situ gene expression signature exists disregarding histopathological classification. Cancer Res. 2004;64:4040-8.

87. Lee J-S, Leem S-H, Lee S-Y, Kim S-C, Park E-S, Kim S-B, Kim S-K, Kim Y-J, Kim W-J, Chu I-S. Expression signature of E2F1 and its associated genes predict superficial to invasive progression of bladder tumors. J Clin Oncol. 2010:28:2660-7.

88. Sanchez-Carbayo M, Socci ND, Lozano J, Saint F, Cordon-Cardo C. Defining molecular profiles of poor outcome in patients with invasive bladder cancer using oligonucleotide microarrays. J Clin Oncol. 2006;24:778-89.

89. Blaveri E, Simko JP, Korkola JE, Brewer JL, Baehner F, Mehta K, Devries S, Koppie T, Pejavar S, Carroll P, Waldman FM. Bladder cancer outcome and subtype classification by gene expression. Clin Cancer Res. 2005;11:4044-55.

90. Lee J, Kotliarova S, Kotliarov Y, Li A, Su Q, Donin NM, Pastorino S, Purow BW, Christopher N, Zhang W, Park JK, Fine HA. Tumor stem cells derived from glioblastomas cultured in bFGF and EGF more closely mirror the phenotype and genotype of primary tumors than do serum-cultured cell lines. Cancer Cell. 2006;9:391-403.

91. Bredel M, Bredel C, Juric D, Harsh GR, Vogel H, Recht LD, Sikic BI. Functional network analysis reveals extended gliomagenesis pathway maps and three novel MYC-interacting genes in human gliomas. Cancer Res. 2005;65:8679-89.

92. Sun L, Hui A-M, Su Q, Vortmeyer A, Kotliarov Y, Pastorino S, Passaniti A, Menon J, Walling J, Bailey R, Rosenblum M, Mikkelsen T, et al. Neuronal and glioma-derived stem cell factor induces angiogenesis within the brain. Cancer Cell. 2006;9:287-300.

93. Murat A, Migliavacca E, Gorlia T, Lambiv WL, Shay T, Hamou M-F, de Tribolet N, Regli L, WickW, Kouwenhoven MCM, Hainfellner JA, Heppner FL, et al. Stem cell-related "self-renewal" signature and high epidermal growth factor receptor expression associated with resistance to concomitant chemoradiotherapy in glioblastoma. J Clin Oncol. 2008:26:3015-24.

94. Talantov D, Mazumder A, Yu JX, Briggs T, Jiang Y, Backus J, Atkins D, Wang Y. Novel genes associated with malignant melanoma but not benign melanocytic lesions. Clin Cancer Res. 2005;11:7234-42.

95. Riker Al, Enkemann SA, Fodstad O, Liu S, Ren S, Morris C, Xi Y, Howell P, Metge B, Samant RS, Shevde LA, LiW, et al. The gene expression profiles of primary and metastatic melanoma yields a transition point of tumor progression and metastasis. BMC Med Genomics. 2008;1:13.

96. Critchley-Thorne RJ, Yan N, Nacu S, Weber J, Holmes SP, Lee PP. Downregulation of the interferon signaling pathway in $\mathrm{T}$ lymphocytes from patients with metastatic melanoma. PLoS Med. 2007;4:e176.

97. Haqq C, Nosrati M, Sudilovsky D, Crothers J, Khodabakhsh D, Pulliam BL, Federman S, Miller JR, Allen RE, Singer MI, Leong SPL, Ljung B-M, et al. The gene expression signatures of melanoma progression. Proc Natl Acad Sci USA. 2005;102:6092-7.

98. Ma X-J, Dahiya S, Richardson E, Erlander M, Sgroi DC. Gene expression profiling of the tumor microenvironment during breast cancer progression. Breast Cancer Res. 2009:11:R7.

99. Curtis C, Shah SP, Chin S-F, Turashvili G, Rueda OM, Dunning MJ, Speed D, Lynch AG, Samarajiwa S, Yuan Y, Gräf S, Ha G, et al. The genomic and transcriptomic architecture of 2000 breast tumours reveals novel subgroups. Nature. 2012;486:346-52. 
100. Radvanyi L, Singh-Sandhu D, Gallichan S, Lovitt C, Pedyczak A, Mallo G, Gish K, Kwok K, Hanna W, Zubovits J, Armes J, Venter D, et al. The gene associated with trichorhinophalangeal syndrome in humans is overexpressed in breast cancer. Proc Natl Acad Sci USA. 2005;102:11005-10.

101. Turashvili G, Bouchal J, Baumforth K, Wei W, Dziechciarkova M, Ehrmann J, Klein J, Fridman E, Skarda J, Srovnal J, Hajduch M, Murray P, et al. Novel markers for differentiation of lobular and ductal invasive breast carcinomas by laser microdissection and microarray analysis. BMC Cancer. 2007;7:55.

102. Zhao H, Langerød A, Ji Y, Nowels KW, Nesland JM, Tibshirani R, Bukholm IK, Kåresen R, Botstein D, Børresen-Dale A-L, Jeffrey SS. Different gene expression patterns in invasive lobular and ductal carcinomas of the breast. Mol Biol Cell. 2004;15:2523-36.

103. Bhattacharjee A, Richards WG, Staunton J, Li C, Monti S, Vasa P, Ladd C, Beheshti J, Bueno R, Gillette M, Loda M, Weber G, et al. Classification of human lung carcinomas by mRNA expression profiling reveals distinct adenocarcinoma subclasses. Proc Natl Acad Sci USA. 2001;98:13790-5.

104. Beer DG, Kardia SLR, Huang C-C, Giordano TJ, Levin AM, Misek DE, Lin L, Chen G, Gharib TG, Thomas DG, Lizyness ML, Kuick R, et al. Geneexpression profiles predict survival of patients with lung adenocarcinoma. Nat Med. 2002;8:816-24.

105. Stearman RS, Dwyer-Nield L, Zerbe L, Blaine SA, Chan Z, Bunn PA, Johnson GL, Hirsch FR, Merrick DT, Franklin WA, Baron AE, Keith RL, et al. Analysis of orthologous gene expression between human pulmonary adenocarcinoma and a carcinogen-induced murine model. Am J Pathol. 2005;167:1763-75.
106. Hou J, Aerts J, den Hamer B, van Ijcken W, den Bakker M, Riegman P, van der Leest C, van der Spek P, Foekens JA, Hoogsteden HC, Grosveld F, Philipsen S. Gene expression-based classification of non-small cell lung carcinomas and survival prediction. PLoS One. 2010;5:e10312.

107. Okayama H, Kohno T, Ishii Y, Shimada Y, Shiraishi K, Iwakawa R, Furuta K, Tsuta K, Shibata T, Yamamoto S, Watanabe S, Sakamoto H, et al. Identification of genes upregulated in ALK-positive and EGFR/KRAS/ ALK-negative lung adenocarcinomas. Cancer Res. 2012;72:100-11.

108. Selamat SA, Chung BS, Girard L, Zhang W, Zhang Y, Campan M, Siegmund KD, Koss MN, Hagen JA, Lam WL, Lam S, Gazdar AF, et al. Genome-scale analysis of DNA methylation in lung adenocarcinoma and integration with mRNA expression. Genome Res. 2012;22:1197-211.

109. Landi MT, Dracheva T, Rotunno M, Figueroa JD, Liu H, Dasgupta A, Mann FE, Fukuoka J, Hames M, Bergen AW, Murphy SE, Yang P, et al. Gene expression signature of cigarette smoking and its role in lung adenocarcinoma development and survival. PLoS One. 2008;3:e1651.

110. Su L-J, Chang C-W, Wu Y-C, Chen K-C, Lin C-J, Liang S-C, Lin C-H, Whang-Peng J, Hsu S-L, Chen C-H, Huang C-YF. Selection of DDX5 as a novel internal control for Q-RT-PCR from microarray data using a block bootstrap re-sampling scheme. BMC Genom. 2007;8:140.

\section{Submit your next manuscript to BioMed Central and we will help you at every step:}

- We accept pre-submission inquiries

- Our selector tool helps you to find the most relevant journal

- We provide round the clock customer support

- Convenient online submission

- Thorough peer review

- Inclusion in PubMed and all major indexing services

- Maximum visibility for your research

Submit your manuscript at www.biomedcentral.com/submit 